\title{
Oxygen-Induced Retinopathy in Mice: Amplification by Neonatal IGF-I Deficit and Attenuation by IGF-I Administration
}

\author{
SOPHIE VANHAESEBROUCK, HANS DANIËLS, LIEVE MOONS, CHRISTINE VANHOLE, PETER CARMELIET, \\ AND FRANCIS DE ZEGHER
}

\author{
Neonatal Intensive Care Unit [S.V., H.D., C.V., F.Z.], University Hospital Gasthuisberg, Leuven, B-3000, Belgium; Vesalius Research \\ Center [S.V., L.M., P.C.], University of Leuven, Leuven, B-3000, Belgium
}

\begin{abstract}
In preterms, low serum levels of IGF (IGF-I) correlate with retinopathy of prematurity (ROP). In mice, IGF-I is a prerequisite for normal retinal development. We further explored the link between IGF-I and oxygen-induced retinopathy (OIR). To assess the role of endogenous IGF-I, pups were redistributed into smaller versus larger litters at birth; in one subgroup, we measured body weight and circulating IGF-I; in another, we applied hyperoxia and assessed retinal neovascularization (NV). To screen for the potential role of exogenous IGF-I, we administered a single bolus of rhIGF-I on postnatal day (P) 4 to pups in normal litters, and applied hyperoxia; body weight and IGF-I were measured; maturation and NV were assessed. Neonatal mice in larger litters had a lower body weight than mice in smaller litters; they had lower levels of circulating IGF-I, and developed more OIR ( $p=$ 0.002). Mice who had received rhIGF-I, weighed more and had higher endogenous IGF-I levels; they matured faster and developed less OIR $(p=0.00001)$. These findings in mice are the first to support the notion that higher availability of endogenous or exogenous IGF-I reduces OIR risk, and thus sharpen the perspective that ROP may be preventable by briefly up-regulating IGF-I after birth. (Pediatr Res 65: 307-310, 2009)
\end{abstract}

$\mathrm{R}$ etinopathy of prematurity (ROP) is a blinding disease initiated by delayed retinal vessel growth and regression of existing vessels after premature birth $(1,2)$. Major risk factors are low gestational age and oxygen; despite more controlled oxygen use, there is no decrease in the overall prevalence of ROP, possibly due to increased survival of very low birth weight infants $(2,3)$.

In humans, ROP risk has been linked to low circulating levels of IGF I (IGF-I) (4,5) and slow postnatal weight gain $(6,7)$. In mice, IGF-I is a prerequisite for normal development of retinal vessels $(8-10)$. These findings have led to the concept that up-regulation of IGF-I shortly after birth may contribute to prevent ROP $(11,12)$. In mice, we further explored the link between circulating IGF-I and oxygeninduced retinopathy (OIR).

Received September 24, 2008; accepted October 13, 2008

Correspondence: Sophie Vanhaesebrouck, M.D., Department of Woman and Child, University of Leuven, 3000 Leuven, Belgium; e-mail: sophie.vanhaesebrouck@ uzleuven.be

Supported in part by Research Grant (OT/04/35) from the University Leuven.

\section{MATERIALS AND METHODS}

Hyperoxia. The murine OIR model of Smith was applied (13). In brief, 7-d-old C57BL/6J WT mice with their dams were exposed to $75 \%$ oxygen for $5 \mathrm{~d}$; on postnatal day $(\mathrm{P}), 12$ the mice were returned to room air. Pups were nursed by their dams; food (standard mouse chow) and water were given ad libitum. Pups were killed on P17 after $5 \mathrm{~d}$ of room air recovery, when retinal neovascularization (NV) is known to peak.

Endogenous IGF-I. Circulating IGF-I levels were measured in prenatal and neonatal mice from normal litters (median 7 pups per litter) from embryonic day (E) 17.5 till P14.

Smaller versus larger litter. As depicted in Figure 1 (panel A), pups from concomitantly born litters were on P1 redistributed among dams, so that there were smaller litters (median, 6 pups; range 4-9) and larger litters (median, 15 pups; range, 14-16). On P7-12, the OIR model was applied. Body weight and circulating IGF-I were measured on P14. Retinal NV was assessed on P17.

Exogenous IGF-I. Larger litter. Pups were randomly assigned to receive placebo (saline) or rhIGF-I (20 $\mu \mathrm{g} / \mathrm{kg}$; R\&D systems, Minneapolis) intraperitoneally (IP) on P4. In total, 125 pups from 10 litters (median, 12 pups, range, $10-18)$ were included, but mortality rate in both subgroups was so elevated $(>90 \%)$ that no meaningful results were obtained.

Normal litter. rhIGF-I doses $<1000 \mu \mathrm{g} / \mathrm{kg}$. Pups were randomly assigned to receive placebo (saline) or rhIGF-I IP on P4. No effect on weight gain was observed with doses of $20,50,100,250 \mu \mathrm{g} / \mathrm{kg}$ tested, respectively, in 21,22 , 85,51 pups (data not shown), but there was an effect with a dose of 1000 $\mu \mathrm{g} / \mathrm{kg}$, which was therefore explored further.

Normal litter. rhIGF-I dose of $1000 \mu \mathrm{g} / \mathrm{kg}$. As depicted in Figure 1 (panel $B$ ), pups (median, 7/litter; range 4-9) were randomly assigned to receive placebo (saline) or $1000 \mu \mathrm{g} / \mathrm{kg}$ of rhIGF-I IP on P4. Thereafter, the OIR model was applied (P7-12). Body weight and maturation were assessed on P7, P14, and P17. Endogenous IGF-I levels were assessed on P14, and NV on P17.

IGF-I Measurement. Mice were anesthetized IP with Nembutal ${ }^{\circledR}(0.1$ $\mathrm{mL} / \mathrm{g}$ of a $1 / 10$ solution). Blood samples were taken from the right ventricle, stored at $37^{\circ} \mathrm{C}$ for $2 \mathrm{~h}$, and centrifuged at $3000 \mathrm{rpm}$. Serum $(5 \mu \mathrm{L})$ was diluted (1/2500), and mIGF-I and hIGF-I were measured by commercially available ELISA (Quantikine, R\&D, Minneapolis). Lower detection limit for the hIGF-I assay was $9.6 \mathrm{ng} / \mathrm{mL}$.

Maturation. In the rhIGF-I study, maturation was assessed by one investigator (HD, blinded to treatment) with observation-behavioral tests on P5, 7, 14, and 17 (skin color; spontaneous and evoked activity) (14), and by another investigator (SV) with a measurement of eye opening on P17. Eye opening was measured to the nearest $0.5 \mathrm{~mm}$ in the longest axis of the eye-split.

The design of the smaller-versus-larger litter study precluded a blinded assessment of maturation.

OIR: Quantitative assessment. On P17, eyes were removed, fixed in 4\% paraformaldehyde for $24 \mathrm{~h}$, and embedded in paraffin. Serial sections of $6 \mu \mathrm{m}$ were cut through the cornea, parallel to the optic nerve, and were either stained with hematoxylin and eosin to assess retinal vasculature by light microscopy $(\times 400)$ or immunolabeled with CD31 to determine the area of

\footnotetext{
Abbreviations: E, embryonic; IP, intraperitoneally; NV, neovascularisation; OIR, oxygen-induced retinopathy; $\mathbf{P}$, postnatal; ROP, retinopathy of prematurity
} 


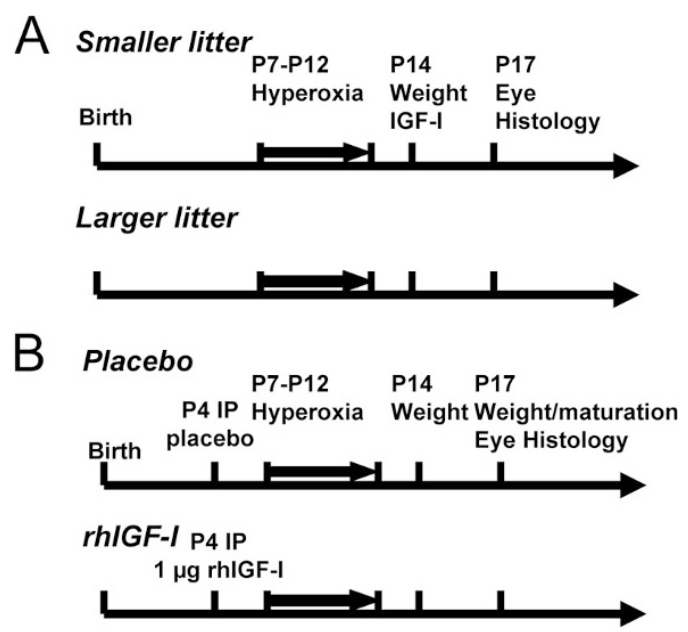

Figure 1. Design of the litter study (panel $A$ ) and design of the rhIGF-I study (panel B).

vaso-obliteration. OIR was quantified by number of NV nuclei per 10 retinal sections, and by fraction (\%) of nonvascularized area.

OIR: Qualitative assessment. On P17, anesthetized mice were perfused through the left ventricle with high molecular weight fluorescein conjugated dextran (Sigma Chemical Co., St. Louis, MO). After perfusion with $1 \mathrm{~mL}$, the eyes were enucleated and placed in $4 \%$ para-formaldehyde for $24 \mathrm{~h}$. Lenses were removed and peripheral retinas cut to allow flat-mounting with Vectashield ${ }^{\circledR}$ medium. Retinas were evaluated by fluorescence microscopy (BX50, Olympus, Japan).

Ethics. Studies were approved by the Institutional Review Board, Centre for Molecular and Vascular Biology, University of Leuven.

Experiments were performed in compliance with the Association for Research in Vision and Ophthalmology statement for the Use of Animals in Ophthalmic and Vision Research.

Statistics. Mann-Whitney $U$ tests and Spearman rank correlation coefficients were used. Cutoff for significance was $p<0.05$, two-tailed. For uniformity, results are presented as medians with interquartile range (IQR).

\section{RESULTS}

Endogenous IGF-I. As depicted in Figure 2, IGF-I levels gradually increased about 6-fold, in normal litters, between birth and P14.

Smaller versus larger litter. As summarized in Table 1, body weight and circulating IGF-I differed by litter size on P14, as did OIR markers on P17. In smaller litters, mice weighed more, had higher IGF-I levels, and displayed less severe OIR. Body weight correlated with IGF-I $(r=0.62 ; p=$ 0.0004). IGF-I correlated with the percentage of nonvascular area $(r=0.53 ; p<0.0001)$ and with the number of NV nuclei $(r=0.53 ; p<0.0001)$. Mortality was similar in smaller and larger litters [6/98 (6\%) versus 16/381 (4\%)].

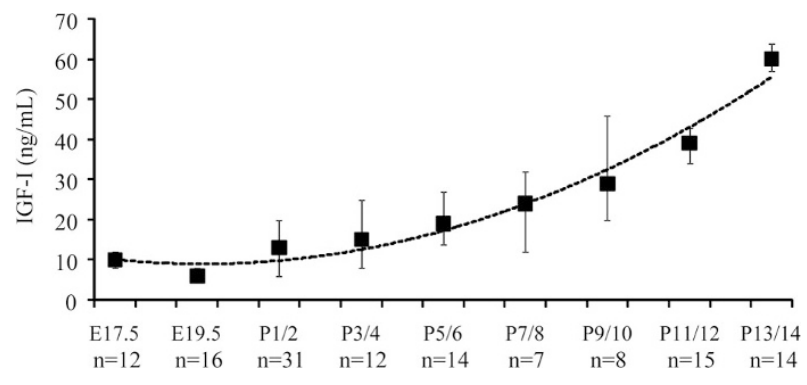

Figure 2. Circulating IGF-I levels from E17.5 till P14.
Table 1. Main results of the litter study

\begin{tabular}{cccc}
\hline & $\begin{array}{c}\text { Smaller litters } \\
\text { (N pups }=92, \\
\text { N litters }=12, \\
\text { median pups/litter }=6)\end{array}$ & $\begin{array}{c}\text { Larger litters } \\
(\mathrm{N} \text { pups }=365,\end{array}$ & $\begin{array}{c}\text { N litters }=23, \\
\text { median pups/litter }=15)\end{array}$ \\
\hline $\begin{array}{c}\text { Weight on } \\
\text { P14 (g) }\end{array}$ & $6.8(5.6-7.4)$ & $4.6(3.4-5.5)$ & 0.001 \\
$\begin{array}{c}\text { IGF-I on P14 } \\
\text { (ng/mL) }\end{array}$ & $70(63-96)$ & $36(9-87)$ & 0.04 \\
$\begin{array}{c}\text { Nonvascular } \\
\text { area (\%) }\end{array}$ & $15(11-28)$ & $33(20-47)$ & 0.002 \\
NV nuclei (\#) & $38(28-70)$ & $82(50-118)$ & 0.002 \\
\hline
\end{tabular}

Values are medians (IQR).

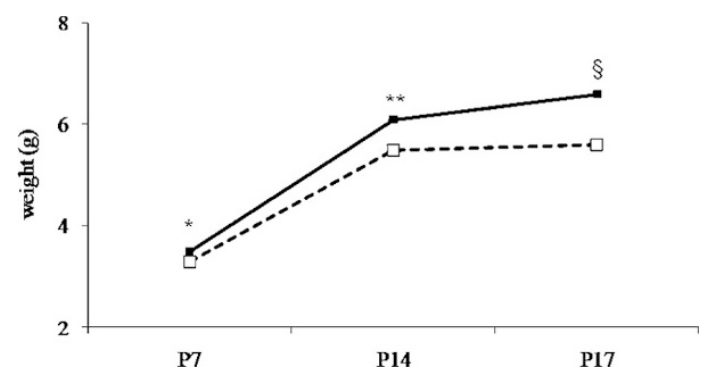

Figure 3. Body weight on P7, P14, and P17 after either placebo or rhIGF-I administration on P4. *, $p<0.05$; **, $p<0.01$;,$p<0.001$ between subgroups. Medians are plotted.

Population, weight, and IGF-I. In total, 150 pups were examined (median, 7 pups/litter; range, 4-9).

Figure 3 shows that rhIGF-I treatment on P4 was followed up by a higher body weight on P7, P14, and P17.

Endogenous IGF-I levels on P14 were higher in rhIGF-Itreated mice than in the placebo subgroup [77 (74-86) ng/mL versus 63 (63-64) ng/mL; $p=0.006]$. Human IGF-I was undetectable on P14.

Maturation. There was no mortality after administration of placebo or rhIGF-I, and spontaneous activity was similar in placebo and rhIGF-I subgroups. However, pups treated with rhIGF-I matured much faster than those given placebo, as

Table 2. Main results of maturation assessment

\begin{tabular}{lccc}
\hline & $\begin{array}{c}\text { Placebo } \\
\text { (N pups }=74,\end{array}$ & $\begin{array}{c}\text { rhIGF-I } \\
\text { (N pups }=76,\end{array}$ & \\
& N litters $=10$, & N litters $=10$, & \\
median pups/litter $=7)$ & median pups/litter $=7)$ & $p$ \\
\hline Skin color & & & \\
P5 & $0(0-0)$ & $0(0-0)$ & NS \\
P7 & $1(1-1)$ & $2(2-2)$ & 0.001 \\
P14 & $1(1-1)$ & $2(2-2)$ & 0.001 \\
P17 & $2(2-2)$ & $2(2-2)$ & NS \\
Evoked activity & & & \\
P5 & $0(0-0)$ & $1(1-0)$ & NS \\
P7 & $1(1-1)$ & $2(1-2)$ & NS \\
P14 & $1(1-1)$ & $2(2-3)$ & 0.03 \\
P17 & $1(1-1)$ & $3(3-3)$ & 0.007 \\
Eye opening & $2(2-2.5)$ & & 0.01 \\
P17 (mm) & & & \\
\hline
\end{tabular}

Values are medians (IQR). Skin color: $0=$ pink, $1=$ gray, $2=$ black; spontaneous and evoked activity: $0=$ none, $1=$ mild, $2=$ moderate, $3=$ pronounced. 

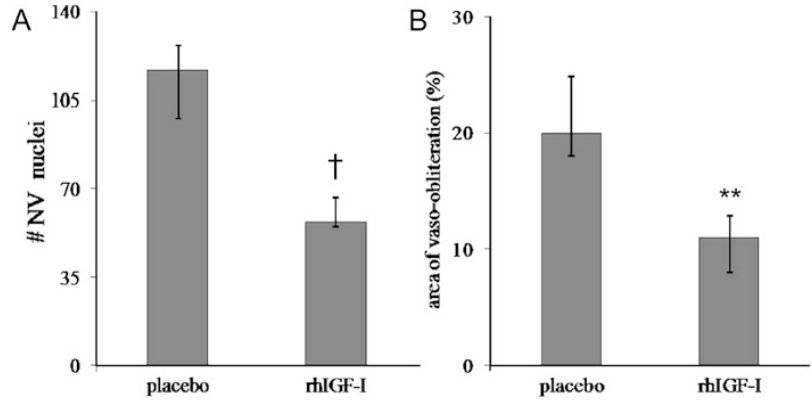

Figure 4. Number of intravitreous NV nuclei per 10 retinal sections on P17 (panel $A$ ) and area of vaso-obliteration $(\%)$ (panel $B$ ) in mice who received either placebo or rhIGF-I on P4. **, $p<0.001 ; \dagger, p<0.0001$.
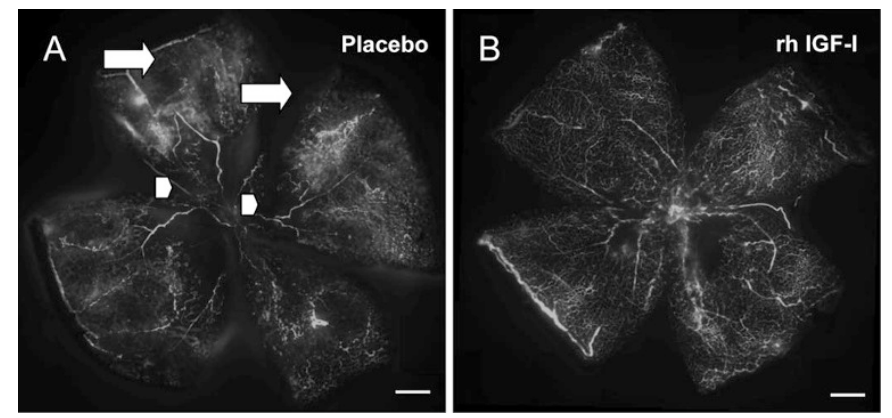

Figure 5. Fluorescence angiography illustrating that rhIGF-I treatment on P4 was accompanied by a reduction of OIR on P17. Retina of placebotreated mice (panel A) were characterized by more drop-out of the peripapillary capillaries, persistence of the large vessels extending radially into the periphery (arrowheads) and more NV tufts at the junction between vascularized and nonvascularised retina (arrows). These hallmarks were less obvious in retina of P17 mice who received rhIGF-I on P4 (panel B). Magnification $\times 5$. Scale bar $200 \mu \mathrm{m}$.

judged by the earlier appearance of black color, evoked activity, and eye opening (Table 2).

OIR. Figure 4 (panel $A$ ) depicts that rhIGF-I treatment on P4 was followed up by a marked reduction $(\sim 50 \%)$ in the number of intravitreous NV nuclei on P17 [117 (98-127) versus 57 (55-67)].

Compared with placebo mice, the rhIGF-I treated mice had a lower fraction of nonvascular area $[20 \%(18-25)$ versus $11 \%(8-13) ; p=0.006$ ] (Fig. 4, panel $B$ ).

Figure 5 shows a fluorescence angiography illustrating that OIR was on P17 more severe in placebo mice.

\section{DISCUSSION}

IGF-I knock-out studies in mice have shown that IGF-I plays a pivotal role in the development of retinal blood vessels (8), but the design of those studies did not allow to differentiate between the roles of prenatal and postnatal IGF-I. A key question in neonatal medicine is whether, after a prenatally normal exposure to IGF-I, the postnatal levels of circulating IGF-I do play a modulating role in the development of ROP. In an attempt to begin addressing this clinically important question, we performed a dual experiment in mice.

A postnatal increment of litter size was associated with a slower gain of body weight, with lower levels of circulating IGF-I, and with a higher sensitivity to OIR. These associations fit well with the clinical observations in preterm newborns that slow postnatal weight gain and low serum levels of IGF-I are risk factors for the development of ROP (5-7).

Conversely, the postnatal administration of an IGF-I bolus was associated with a faster gain of weight, with an accelerated maturation, and with a reduced sensitivity to OIR. It is conceivable that exogenous IGF-I accelerates weight gain by stimulating intestinal growth and maturation, which, in turn, allow for more nutritional uptake and more generation of endogenous IGF-I (15). In the large litters, part of the high mortality after IGF-I administration may be because of the impossibility to increase nutritional intake.

Collectively, the present results support the concept that postnatal IGF-I modulates not only neonatal weight gain and maturation, but also the neonatal sensitivity to OIR. In rats (16-18), neonatal growth restraint has long been linked to an amplified sensitivity to OIR, but the underpinning mechanisms remained poorly understood; the present findings in mice suggest that the nutritional control of circulating IGF-I may be among the mediators of such a link.

One of the limitations of the study is that we failed to establish the extent to which the tested rhIGF-I bolus resulted in a supra-physiologic IGF-I exposure. A broader spectrum of rhIGF-I regimens remains to be explored, for example, with other doses, timings, and routes of rhIGF-I administration.

Independent of the mechanisms that will prove to mediate the actions of postnatal IGF-I on the neonatal sensitivity to OIR, our findings sharpen the perspective that ROP may ultimately be attenuated or even be prevented by raising the neonatal levels of circulating IGF-I, either directly (by giving exogenous rhIGF-I) or indirectly (by giving insulin, which can increase endogenous IGF-I) (19).

Acknowledgments. We thank Ann Bouché, Ann Manderveld, and Maria De Mol for technical assistance.

\section{REFERENCES}

1. Smith LE 2004 Pathogenesis of retinopathy of prematurity. Growth Horm IGF Res 14:S140-S144

2. Chen J, Smith LE 2007 Retinopathy of prematurity. Angiogenesis 10:133-140

3. Yeung MY 2006 Somatotropic axis derangement as an underlying factor in the genesis of retinopathy of prematurity. Acta Paediatr 95:1334-1340

4. Hellström A, Engström E, Hård AL, Albertsson-Wikland K, Carlsson B, Niklasson A, Löfqvist C, Svensson E, Holm S, Ewald U, Holmström G, Smith LE 2003 Postnatal serum insulin-like growth factor I deficiency is associated with retinopathy of prematurity and other complications of premature birth. Pediatrics 112:1016-1020

5. Löfqvist C, Andersson E, Sigurdsson J, Engström E, Hård AL, Niklasson A, Smith LE, Hellström A 2006 Longitudinal postnatal weight and insulin-like growth factor I measurements in the prediction of retinopathy of prematurity. Arch Ophthalmol 124:1711-1718

6. Wallace DK, Kylstra JA, Phillips SJ, Hall JG 2000 Poor postnatal weight gain: a risk factor for severe retinopathy of prematurity. J AAPOS 4:343-347

7. Allegaert K, Vanhole C, Casteels I, Naulaers G, Debeer A, Cossey V, Devlieger H 2003 Perinatal growth characteristics and associated risk of developing threshold retinopathy of prematurity. J AAPOS 7:34-37

8. Hellstrom A, Perruzzi C, Ju M, Engstrom E, Hard AL, Liu JL, AlbertssonWikland K, Carlsson B, Niklasson A, Sjodell L, LeRoith D, Senger DR, Smith LE 2001 Low IGF-I suppresses VEGF-survival signaling in retinal endothelial cells: direct correlation with clinical retinopathy of prematurity. Proc Natl Acad Sci USA 98:5804-5808

9. Hellström A, Carlsson B, Niklasson A, Segnestam K, Boguszewski M, de Lacerda L, Savage M, Svensson E, Smith L, Weinberger D, Albertsson Wikland K, Laron Z 2002 IGF-I is critical for normal vascularization of the human retina. J Clin Endocrinol Metab 87:3413-3416 
10. Smith LE 2005 IGF-1 and retinopathy of prematurity in the preterm infant. Biol Neonate 88:237-244

11. Smith LE 2004 Can we restore aspects of the in utero environment in premature infants to prevent disease? Pediatrics 114:491

12. Lofqvist C, Chen J, Connor KM, Smith AC, Aderman CM, Liu N, Pintar JE, Ludwig T, Hellstrom A, Smith LE 2007 IGFBP3 suppresses retinopathy through suppression of oxygen-induced vessel loss and promotion of vascular regrowth. Proc Natl Acad Sci USA 104:10589-10594

13. Smith LE, Wesolowski E, McLellan A, Kostyk SK, D’Amato R, Sullivan R, D'Amore PA 1994 Oxygen-induced retinopathy in the mouse. Invest Ophthalmol Vis Sci 35:101-111

14. Hinde R 1966 Animal Behaviour, a Synthesis of Ethology and Comparative Psychology. McGraw-Hill Kogakusha, Tokio
15. Murali SG, Nelson DW, Draxler AK, Liu X, Ney DM 2005 Insulin-like growth factor-I attenuates jejunal atrophy in association with increased expression of IGF-I binding protein-5 in parenterally fed mice. J Nutr 135:2553-2559

16. Holmes JM, Duffner LA 1995 The effect of litter size on normal retinal vascular development in the neonatal rat. Curr Eye Res 14:737-740

17. Holmes JM, Duffner LA 1996 The effect of postnatal growth retardation on abnormal neovascularization in the oxygen exposed neonatal rat. Curr Eye Res 15:403-409

18. Floyd BN, Leske DA, Wren SM, Mookadam M, Fautsch MP, Holmes JM 2005 Differences between rat strains in models of retinopathy of prematurity. Mol Vis 11:524-530

19. Beardsall K, Ogilvy-Stuart AL, Frystyk J, Chen JW, Thompson M, Ahluwalia J, Ong KK, Dunger DB 2007 Early elective insulin therapy can reduce hyperglycemia and increase insulin-like growth factor-I levels in very low birth weight infants. J Pediatr 151:611-617 